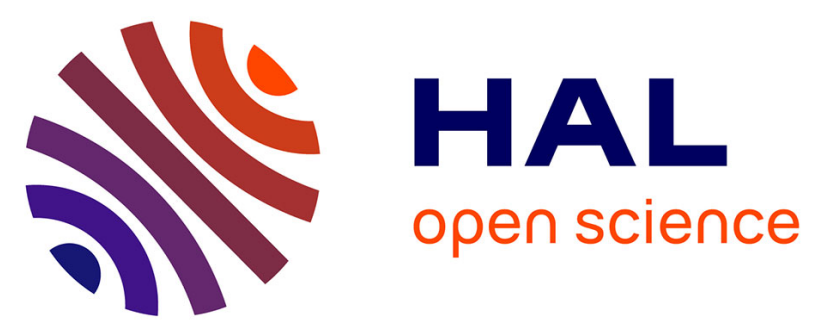

\title{
Copolymeric films obtained by electropolymerization of porphyrins and dipyridyl-spacers including Dawson-type polyoxometalates
}

Zhaohui Huo, Iban Azcarate, Rana Farha, Michel Goldmann, Hualong Xu, Bernold Hasenknopf, Emmanuel Lacote, Laurent Ruhlmann

\section{To cite this version:}

Zhaohui Huo, Iban Azcarate, Rana Farha, Michel Goldmann, Hualong Xu, et al.. Copolymeric films obtained by electropolymerization of porphyrins and dipyridyl-spacers including Dawson-type polyoxometalates. Journal of Solid State Electrochemistry, 2015, 19 (9), pp.2611-2621. 10.1007/s10008015-2828-5 . hal-01445610

\author{
HAL Id: hal-01445610 \\ https://hal.science/hal-01445610
}

Submitted on 1 Oct 2021

HAL is a multi-disciplinary open access archive for the deposit and dissemination of scientific research documents, whether they are published or not. The documents may come from teaching and research institutions in France or abroad, or from public or private research centers.
L'archive ouverte pluridisciplinaire HAL, est destinée au dépôt et à la diffusion de documents scientifiques de niveau recherche, publiés ou non, émanant des établissements d'enseignement et de recherche français ou étrangers, des laboratoires publics ou privés.

\section{(c)(1)}

Distributed under a Creative Commons Attribution| 4.0 International License 


\title{
Copolymeric films obtained by electropolymerization of porphyrins and dipyridyl-spacers including Dawson-type polyoxometalates
}

\author{
Zhaohui Huo $^{1}$ - Iban Azcarate ${ }^{2,3} \cdot$ Rana Farha ${ }^{4,5}$ - Michel Goldmann ${ }^{4,6} \cdot$ Hualong $\mathrm{Xu}^{7}$. \\ Bernold Hasenknopf ${ }^{2,3} \cdot$ Emmanuel Lacôte $^{8,9} \cdot$ Laurent Ruhlmann ${ }^{1}$
}

\begin{abstract}
This paper reports the formation of hybrid polyoxometalate-porphyrin copolymeric films obtained by the electro-oxidation of zinc- $\beta$-octaethylporphyrin (ZnOEP) in the presence of a functionalized Dawsontype polyoxometalate bearing two pyridyl groups (POMdb me $^{3,3}$, Py-POM-Py) which will be compared to the copolymer obtained from ZnOEP and a dipyridyl compound without POM $\left(\mathrm{ib}_{\mathrm{me}} 3,3\right)$. The resulting film has been characterized by UV-visible absorption spectroscopy, X-ray photoelectron spectroscopy, and atomic force microscopy. Electrochemical quartz crystal microbalance was employed to investigate the poly-porphyrinPOMs deposition mass.
\end{abstract}

Laurent Ruhlmann lruhlmann@unistra.fr

1 Laboratoire d'Electrochimie et de Chimie Physique du Corps Solide, Université de Strasbourg, Institut de Chimie, UMR CNRS 7177, 4 rue Blaise Pascal, CS 90032, 67081 Strasbourg cedex, France

2 Institut Parisien de Chimie Moléculaire, Sorbonne Universités, UPMC Univ Paris 6, UMR 8232, 4 Place Jussieu, 75005 Paris, France

3 CNRS, Institut Parisien de Chimie Moléculaire, UMR 8232, 4 Place Jussieu, 75005 Paris, France

4 Institut des NanoSciences de Paris, UMR CNRS 7588, Université Paris 6, 4 place Jussieu, boîte courrier 840, 75252 Paris, France
Keywords Copolymer $\cdot$ Polyoxometalate $\cdot$ Porphyrin · Electropolymerization $\cdot$ EQCM

\section{Introduction}

Polyoxometalates (POMs) form a unique class of inorganic metal-oxygen cluster compounds with applications in medicine, analytical chemistry, catalysis, electronic, and materials science [1]. They are negatively charged electron acceptors which can undergo multi-electron redox processes without decomposition which are the basis for numerous catalytic processes $[1,2]$. In most of the

5 Laboratoire d'Analyse et Contrôle des Systèmes Complexes - LACS C-ECE Paris Ecole d'Ingénieurs, 37 Quai de Grenelle, 75015 Paris, France

6 Université Paris Descartes, 45 rue des Saints Pères, 75006 Paris, France

7 Department of Chemistry, Shanghai Key Laboratory of Molecular Catalysis and Innovative Materials and Laboratory of Advanced Materials, Fudan University, Shanghai 200433, People's Republic of China

8 ICSN CNRS, Av. de la Terrasse, 91198 Gif-sur-Yvette Cedex, France

9 Institut de chimie de Lyon, Université de Lyon, UMR 5265 CNRSUniversité Lyon I-ESCPE Lyon, 43 Bd du 11 novembre 1918, 69616 Villeurbanne, France 
cases, POMs reach excited states only under UV irradiation $(\mathrm{O} \rightarrow \mathrm{M}$ LMCT absorption band) [3]. To diversify the practical applications, their association to a lightharvesting antenna is so far required.

Organo-POMs represent an approach to overcome part of these limitations $[4,5,6,7,8]$. Photon absorptions can be improved with visible light sensitive dyes linked to the POMs. In many examples of POM-dye materials reported in the literature, the hybrids were assembled via electrostatic interactions. These devices are easily achieved, but they suffer from the absence of organizational and structural control. Some POM-porphyrin coordination complexes were also described $[9,10,11,12]$. Peng has reported the synthesis of an $\mathrm{Fe}$ (terpyridine) ${ }_{2}$-Lindqvist molybdate coordination polymer [13]. Ruhlmann and Hasenknopf published the formation of axial coordination of the polyoxometalate-grafted pyridyl groups to the metal ion in $[\mathrm{Ru}(\mathrm{CO}) \mathrm{TPP}](\mathrm{TPP}=$ tetraphenylporphyrin) or ZnTPP metalloporphyrin [10], or also the reverse strategy where porphyrin-grafted pyridyl groups were coordinated to $\alpha$-[ $\left.\mathrm{MSiW}_{11} \mathrm{O}_{39}\right]^{6-}$ Keggin-type POMs $\left(\mathrm{M}=\mathrm{Co}^{2+}\right.$ and $\left.\mathrm{Ni}^{2+}\right)$ [12]. More and more efforts are made on covalently attached dyes on POMs $[14,15,16,17$, $18,19,20,21,22,23]$. The covalent methodology offers numerous advantages; in particular it should improve the relative orientation of the organic and inorganic components, and thus the directionality and strengths of the interactions. Several examples have been published such as ferrocenyl [14, 15], pyrene, and perylene $[16,17,18]$. Ru and Ir complexes [17, 19], or porphyrins [20, 21, 22, 23], grafted onto POMs.
Recently, we reported the formation via a novel and original electropolymerization process, of mixed POM-porphyrin copolymer films with zinc- $\beta$-octaethyl porphyrin (ZnOEP) and either an Anderson-type POM $\left[\mathrm{MnMo}_{6} \mathrm{O}_{18}\left\{\left(\mathrm{OCH}_{2}\right)_{3} \mathrm{CNHCO}(4-\right.\right.$ $\left.\left.\left.\mathrm{C}_{5} \mathrm{H}_{4} \mathrm{~N}\right)\right\}_{2}\right]^{3-}$, or organic derivatives of the Dawson type POM $\left[\mathrm{P}_{2} \mathrm{~W}_{15} \mathrm{~V}_{3} \mathrm{O}_{62}\right]^{9-}$ bearing various dipyridyl ligands $[24,25]$. All of them displayed interesting photocatalytic properties under visible light illumination. Therefore, we believe that it would be of great interest to form new covalent POM-porphyrin copolymers by varying the type of POM, and to study the role of the POM in the polymer backbone. Thus, in the present paper, we report the electropolymerization of $\mathrm{ZnOEP}$ in the presence of a functionalized Dawson-type polyoxometalate bearing two pyridyl groups (POM- $\mathrm{db}_{\mathrm{me}} 3,3$, Scheme 1) which will be compared to the copolymer obtained from $\mathrm{ZnOEP}$ and a dipyridyl compound without POM ( $\mathrm{ib}_{\mathrm{me}} 3,3$, Scheme 2). The copolymers have been characterized by UV-vis spectroscopy, X-ray photoelectron spectra (XPS), atomic force micrographs (AFM), EQCM, and electrochemistry.

\section{Experimental}

\section{Reagent and apparatus}

All solvents were of reagent grade quality and used without further purification. The zinc- $\beta$-octaethylporphyrin ( $\mathrm{ZnOEP}$ ) was purchased from Sigma-Aldrich. The syntheses of the

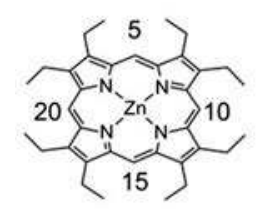

ZnOEP

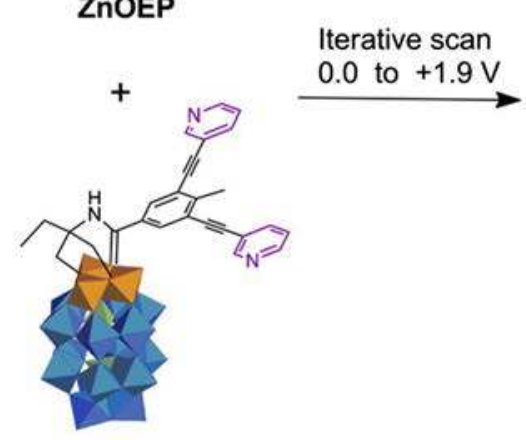

POM- $\mathrm{db}_{\mathrm{me}} 3,3$

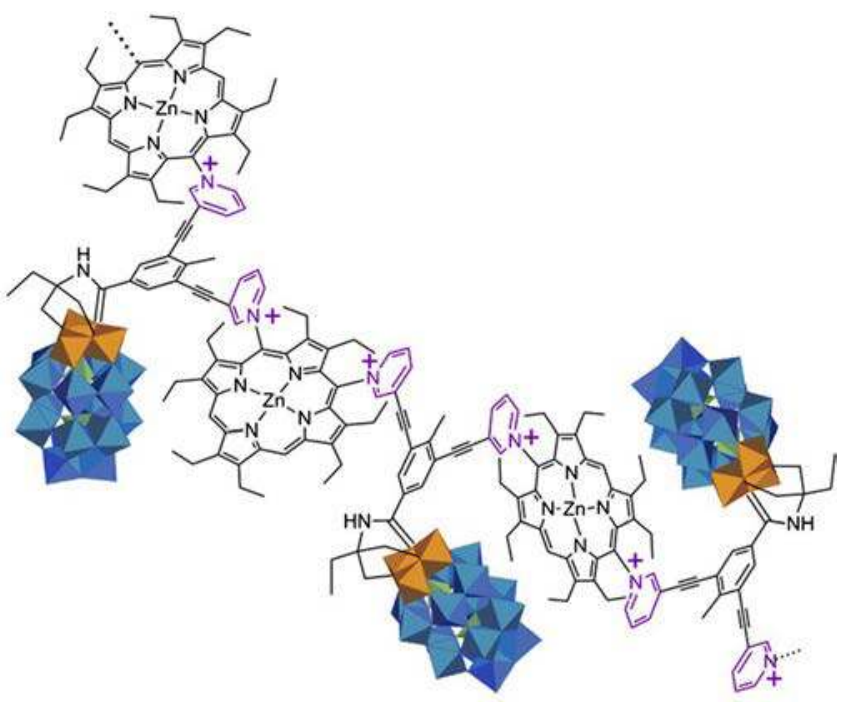

poly-POM-db ${ }_{m e} 3,3-Z n O E P$

Scheme 1 Copolymer poly-POM-db $\mathrm{me}_{\mathrm{m}} 3,3$-ZnOEP, obtained with $\mathrm{ZnOEP}$ and POM- $\mathrm{db}_{\mathrm{me}} 3,3.5,10,15$, and 20 correspond to the four meso-positions of the $\mathrm{ZnOEP}$ 


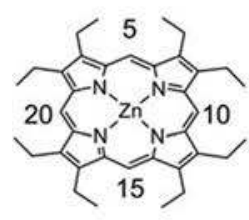

ZnOEP

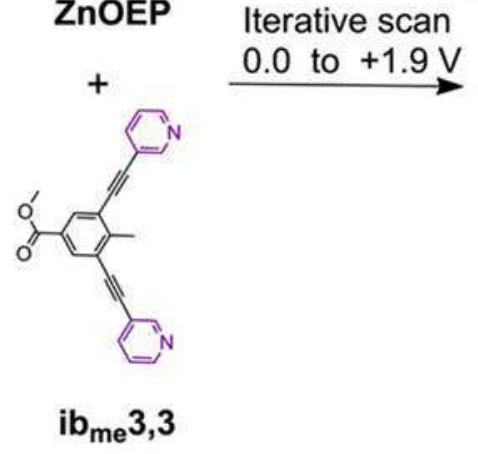

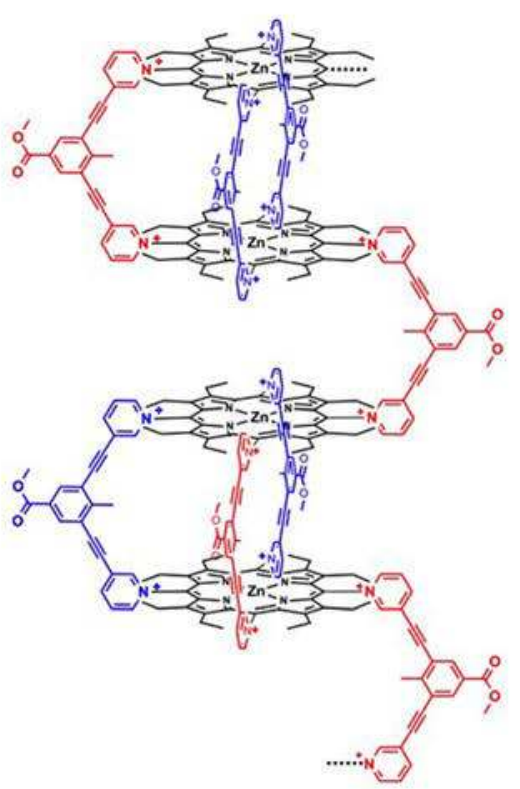

poly-ib me $^{3,3-Z n O E P}$

Structure 1

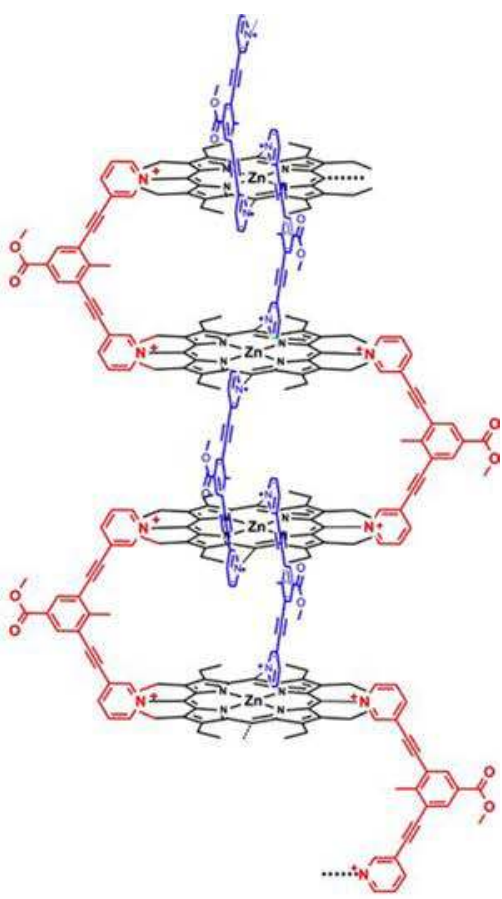

poly-ib $\mathrm{me}_{\mathrm{m}} 3,3-\mathrm{ZnOEP}$ Structure 2
Scheme 2 Copolymer poly-ib 3 3,3-ZnOEP, obtained with ZnOEP and $\mathrm{ib}_{\mathrm{me}} 3,3$. In order to be more clear, two different colors (blue and red) have been used to represent the di-pyridinium spacers between porphyrins.

$\mathrm{ib}_{\mathrm{me}} 3,3$ and POM- $\mathrm{db}_{\mathrm{me}} 3,3$ is described in the electronic supporting information.

Voltammetric data have been recorded with a standard three-electrode system using a PARSTAT 2273 potentiostat. The electrolyte was $\mathrm{CH}_{3} \mathrm{CN} / 1,2-\mathrm{C}_{2} \mathrm{H}_{4} \mathrm{Cl}_{2}$ (3/7) containing $0.1 \mathrm{~mol} \mathrm{~L}^{-1}$ of tetrabutylammonium hexafluorophosphate $\left(\mathrm{NBu}_{4} \mathrm{PF}_{6}\right)$. Glass plates single-side coated with indium-tinoxide (ITO, SOLEMS, $25-35 \Omega / \mathrm{cm}^{2}$ ) with a surface area of $1 \mathrm{~cm}^{2}$ were used as working electrode, a platinum wire as auxiliary electrode and the reference electrode was the Saturated Calomel Electrode (SCE) electrically connected to the solution by a junction bridge filled with electrolyte. The ITO electrodes were also used to obtain UV-vis spectra of the electrochemically deposited copolymers on an Agilent 8453 spectrophotometer.

A QCA-922 (SEIKO EG\&G instrument) system combined with Versa STAT 3 was used for simultaneous electrochemical quartz crystal measurement (EQCM) and cyclic voltammetric measurements. The electrochemical cell was assembled in a glove box using an ITO AT-cut quartz crystal resonator (mirror finished; resonant frequency, $9.08 \mathrm{MHz} \pm 50 \mathrm{kHz} ; A=0.2 \mathrm{~cm}^{2}$; SEIKO EG\&G., LTD) as working electrode, a platinum wire as counter electrode,
Probably in the copolymer the two proposed structures coexist, moreover various combination, especially for the position of the spacer can be proposed

and a $\mathrm{Ag} / \mathrm{AgCl}$ wire as a quasi-reference electrode. The solution used for the electropolymerization here is the same as the one we used for electropolymerization of the copolymers with the larger ITO electrode. Iterative scans were conducted at a scan rate of $100 \mathrm{mV} \mathrm{s}^{-1}$ at room temperature with simultaneous recording of the quartz resonance frequency. The change of the quartz resonance frequency $(\Delta f)$ was converted into the mass change $(\Delta m)$ on the ITO-coated quartz during iterative cycling by applying Sauerbrey's equation (Eq. 1):

$\Delta f=-2 f_{0}^{2} \Delta m / A(\mu \cdot \rho)^{1 / 2}$

where $f_{0}$ is the resonant frequency of the fundamental mode, $\rho$ is density of the crystal $\left(2.684 \mathrm{~g} \mathrm{~cm}^{-3}\right), A$ is working area $\left(0.2 \mathrm{~cm}^{2}\right)$ of the ITO quartz crystal resonator, $\mu$ is shear modulus of quartz $\left(2.947 \times 10^{11} \mathrm{~g} \mathrm{~cm}^{-1} \mathrm{~s}^{-2}\right)$. In the conditions the Sauerbrey's equation (Eq. 1) can be used to calculate the mass of deposition $\Delta m$ since our deposition yields a rigid and evenly distributed mass, and the frequency change is more than $2 \%$ of the frequency.

XPS experiments were carried out on a RBD upgraded PHI-5000C ESCA system (PerkinElmer) with MgKR 
radiation $(h=1,253.6 \mathrm{eV})$ or $\mathrm{Al} \mathrm{KR}$ radiation $(h=1,486.6 \mathrm{eV})$. In general, the X-ray anode was run at $250 \mathrm{~W}$ and the high voltage was kept at $14.0 \mathrm{kV}$ with a detection angle at $54^{\circ}$. The pass energy was fixed at 23.5, 46.95, or $93.90 \mathrm{eV}$ to ensure sufficient resolution and sensitivity. The base pressure of the analyzer chamber was about $5 \times 10^{-8} \mathrm{~Pa}$. The sample was directly pressed to a self-supported disk $(10 \times 10 \mathrm{~mm})$ and mounted on a sample holder then transferred into the analyzer chamber. The whole spectra $(0-1,100 \mathrm{eV})$ and the narrow spectra of all the elements with higher resolution were both recorded by using RBD 147 interface (RBD Enterprises, U.S.A.) through the Auger Scan 3.21 software. Binding energies were calibrated by using the containment carbon $(\mathrm{C} 1 \mathrm{~s}=$ $284.6 \mathrm{eV})$. The data analysis was carried out by using the RBD Auger Scan 3.21 software of RBD Enterprises or XPS Peak4.1 provided by Raymund W.M. Kwok (The Chinese University of Hong Kong, China).

AFM measurements have been conducted directly on the ITO surfaces using a Veeco Dimension 3100 apparatus in the tapping mode under ambient conditions. Silicon cantilevers (Veeco probes) with a spring constant of $300 \mathrm{~N} / \mathrm{m}$ and a resonance frequency in the range of $120-139 \mathrm{kHz}$ have been used. The scanning rate was $1.0 \mathrm{~Hz}$.

\section{Synthesis of the poly-ib $\mathrm{me}^{3,3-\mathrm{ZnOEP}}$ and poly-POM-db me $^{3,3-Z n O E P}$}

ITO electrodes, with a surface of about $1 \mathrm{~cm}^{2}$, were used as working electrode. For each polymer, the number of scans $(n)$ involved in the iterative procedure was varied in order to modulate the thickness of the films. Electropolymerizations have been carried out under an argon atmosphere using a $0.1 \mathrm{~mol} \mathrm{~L}^{-1}$ solution of $\mathrm{NBu}_{4} \mathrm{PF}_{6}$ in $1,2-\mathrm{C}_{2} \mathrm{H}_{4} \mathrm{Cl}_{2} / \mathrm{CH}_{3} \mathrm{CN}(7 / 3)$ containing $2.5 \times$ $10^{-4} \mathrm{~mol} \mathrm{~L}^{-1}$ of $\mathrm{ZnOEP}\left(598.15 \mathrm{~g} \mathrm{~mol}^{-1}\right.$ ) and $2.5 \times$ $10^{-4} \mathrm{~mol} \mathrm{~L}^{-1}$ of $\mathrm{ib}_{\mathrm{me}} 3,3\left(352.12 \mathrm{~g} \mathrm{~mol}^{-1}\right)$ or POM$\mathrm{db}_{\text {me }} 3,3\left(5586.40 \mathrm{~g} \mathrm{~mol}^{-1}\right)$. Scanning experiments have been carried out at a scan rate of $0.1 \mathrm{~V} / \mathrm{s}$ between 0.00 and $+1.90 \mathrm{~V}$ vs. SCE or between -1.30 and $+1.90 \mathrm{~V}$ vs. SCE. After electropolymerization, the modified working electrodes were washed with $\mathrm{CH}_{3} \mathrm{CN}$ and then with $\mathrm{CH}_{2} \mathrm{Cl}_{2}$ in order to remove the monomers and the conducting salt present on the deposited films.

\section{Results and discussion}

\section{Synthesis of the poly-ib ${ }_{\text {me }} 3,3-\mathrm{ZnOEP}$ and poly-POM-db ${ }_{\text {me }} 3,3-\mathrm{ZnOEP}$}

The syntheses of the copolymers were achieved via our electropolymerization method, as reported earlier [26,
27]. It relies on the reaction of the dipyridylsubstituted Dawson-type polyoxometalate POM- $\mathrm{db}_{\mathrm{me}} 3,3$ (Scheme 1) or of the dipyridyl compound $\mathrm{ib}_{\mathrm{me}} 3,3$ (Scheme 2) with an electro-generated dicationic porphyrin by iterative scans between -1.13 and $+1.90 \mathrm{~V}$ vs. SCE or 0.00 and $+1.90 \mathrm{~V}$ vs. SCE (Figs. 1 and 2) [24, 27]. The reaction mechanism corresponds to the previously reported EPOP process of nucleophilic substitution on porphyrins $[28.29,30,31,32,33,34,35]$. The procedure required in the present case is the formation of the dication; the singly oxidized porphyrin radical monocation was not reactive enough, probably because of kinetic problems. Therefore, an $\mathrm{E}_{1}\left(\mathrm{E}_{2 i} \mathrm{CN}_{\text {meso }} \mathrm{E}_{2 i+1} \mathrm{C}_{\mathrm{B}}\right)_{i=1 \rightarrow n} \mathrm{E}_{2(n+1)}$ mechanism can be suggested to describe the electropolymerization route where $\mathrm{C}_{\mathrm{Nmeso}}$ corresponds to the nucleophilic attack at the meso position of the porphyrin which forms an
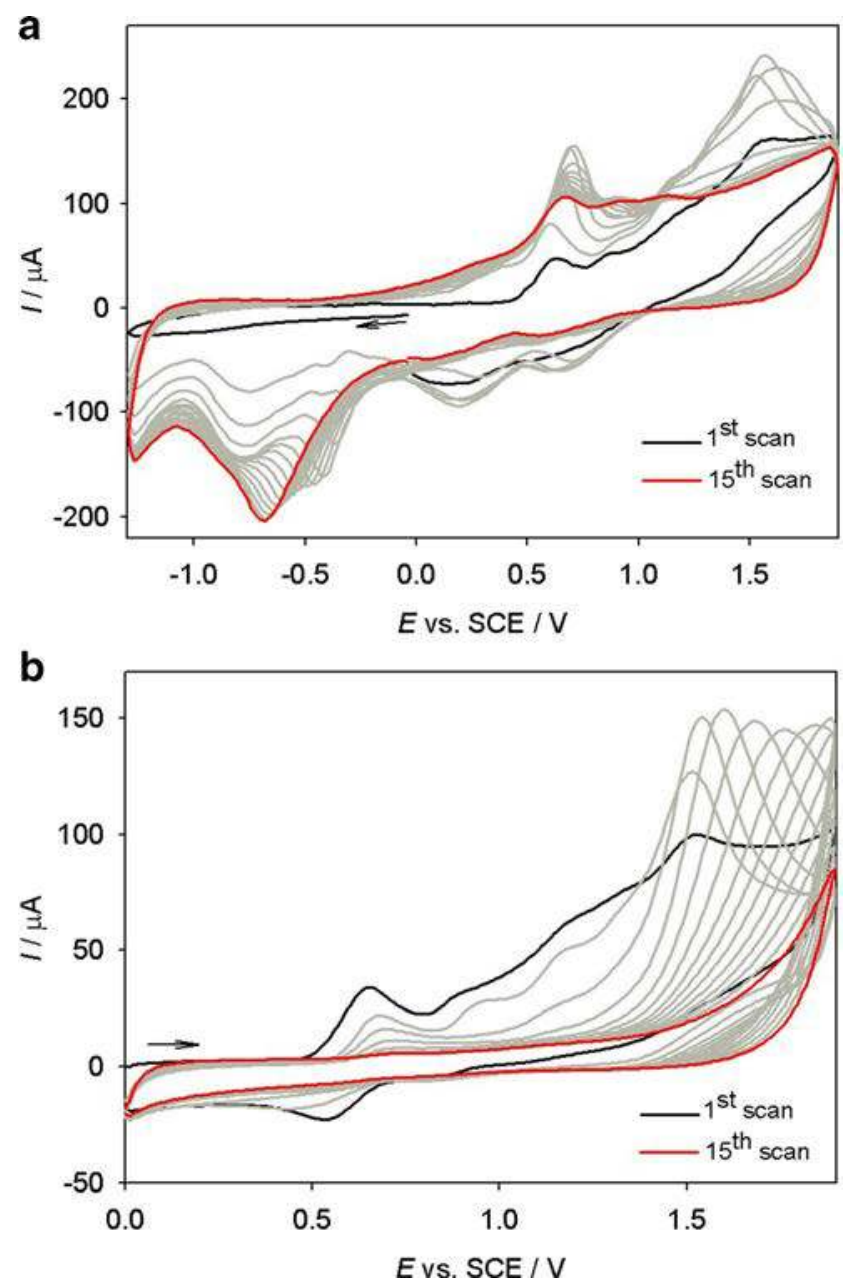

Fig. 1 Cyclic voltammograms for the electropolymerization of $\mathrm{ZnOEP}$ $\left(0.25 \mathrm{mmol} \mathrm{L}^{-1}\right)$ with ib $\mathrm{me}_{\mathrm{m}} 3,3\left(0.25 \mathrm{mmol} \mathrm{L}^{-1}\right)$ in $1,2-\mathrm{C}_{2} \mathrm{H}_{4} \mathrm{Cl}_{2}-\mathrm{CH}_{3} \mathrm{CN}$ (7/3) $\mathrm{NBu}_{4} \mathrm{PF}_{6} 0.1 \mathrm{~mol} \mathrm{~L}^{-1}$. Working electrode: ITO. $S=1 \mathrm{~cm}^{2}$. Scan rate: $0.1 \mathrm{~V} \mathrm{~s}^{-1} .(\leftarrow)$ Start of the scan. Cyclic scanning $\left(0.1 \mathrm{~V} \mathrm{~s}^{-1}\right)$ was applied at potentials between a) -1.30 and $+1.90 \mathrm{~V}$ vs. SCE and b) between 0.00 and $+1.90 \mathrm{~V}$ vs. SCE 

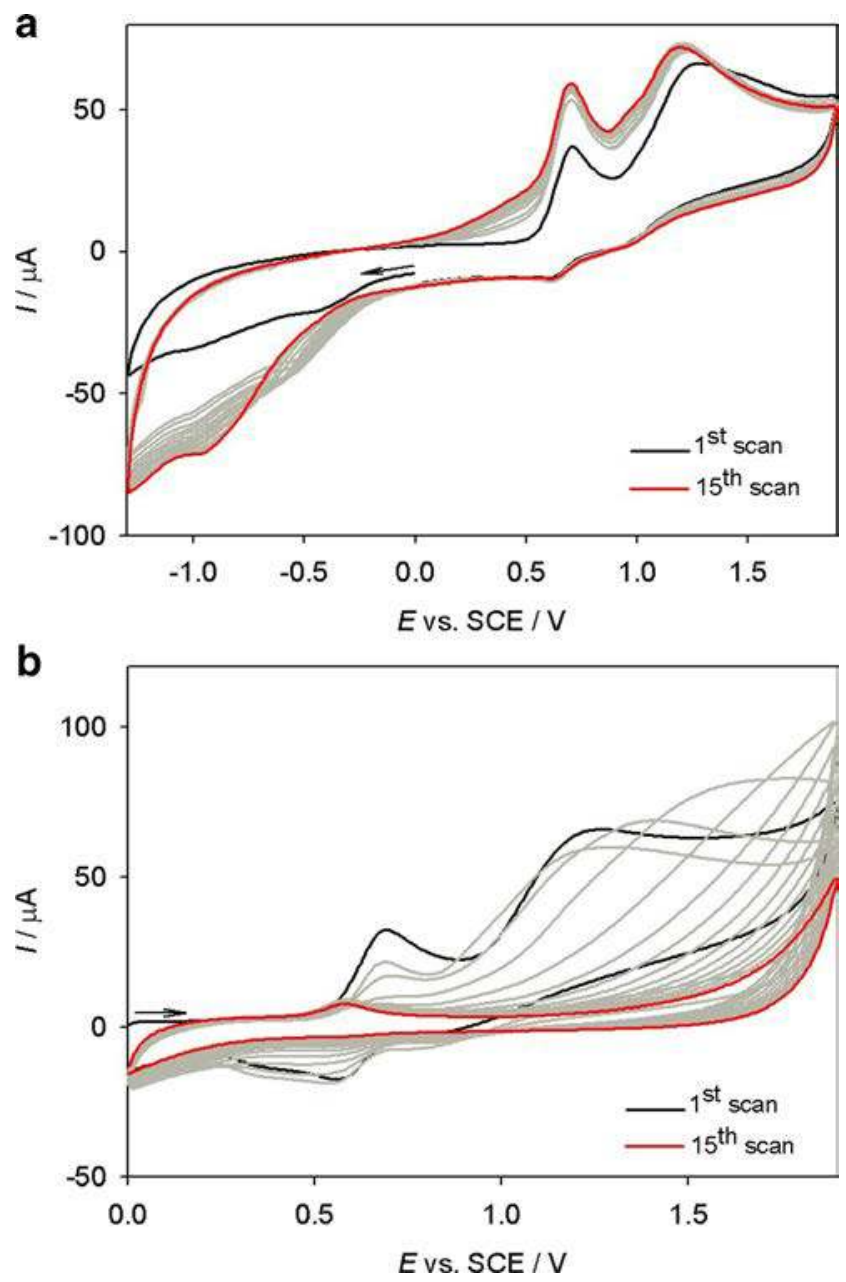

Fig. 2 Cyclic voltammograms for the electropolymerization of $\mathrm{ZnOEP}$ $\left(0.25 \mathrm{mmol} \mathrm{L}^{-1}\right)$ with POM-db $\mathrm{me}^{3,3}\left(0.25 \mathrm{mmol} \mathrm{L}^{-1}\right)$ in $1,2-\mathrm{C}_{2} \mathrm{H}_{4} \mathrm{Cl}_{2}-$ $\mathrm{CH}_{3} \mathrm{CN}(7 / 3) \mathrm{NBu}_{4} \mathrm{PF}_{6} 0.1 \mathrm{~mol} \mathrm{~L}$. Working electrode: ITO. $S=1 \mathrm{~cm}^{2}$. Scan rate, $0.1 \mathrm{~V} \mathrm{~s}^{-1}$. (Leftwards arrow) Start of the scan. Cyclic scanning $\left(0.1 \mathrm{~V} \mathrm{~s}^{-1}\right)$ was applied at potentials between $\mathbf{a}-1.30$ and $+1.90 \mathrm{~V}$ vs. SCE and $\mathbf{b}$ between 0.00 and $+1.90 \mathrm{~V}$ vs. SCE

isoporphyrin [27]. The overall reaction, for a degree of polymerization $n$, can be written as (Eq. 2):

$$
\begin{aligned}
(n & +1) \mathrm{ZnOEP}+(n+1) \mathrm{Py}-R-\mathrm{Py} \rightarrow \mathrm{ZnOEP} \\
& +\left(\mathrm{Py}^{+}-R-\mathrm{Py}^{+}-\mathrm{ZnOEP}\right)_{n}-\mathrm{Py}^{+}-R-\mathrm{Py} \\
& +(2 n+1) \mathrm{H}^{+}+(4 n+2) \mathrm{e}^{-}
\end{aligned}
$$

where $R$ is the spacer between the two pyridyl groups. The reactions consequently generate $\mathrm{H}^{+}$ions, which can induce the demetalation of ZnOEP and stop the reaction. In our case, the protons generated did not disturb the coating of the electrodes because of the large volume of solution used. The absence of demetalation of ZnOEP was confirmed by UV-visible spectroscopy.

In the case of the formation of poly-ZnOEP-ib $\mathrm{me}^{3,3}$ (Fig. 1), iterative scans between -1.30 and $+1.60 \mathrm{~V}$ lead
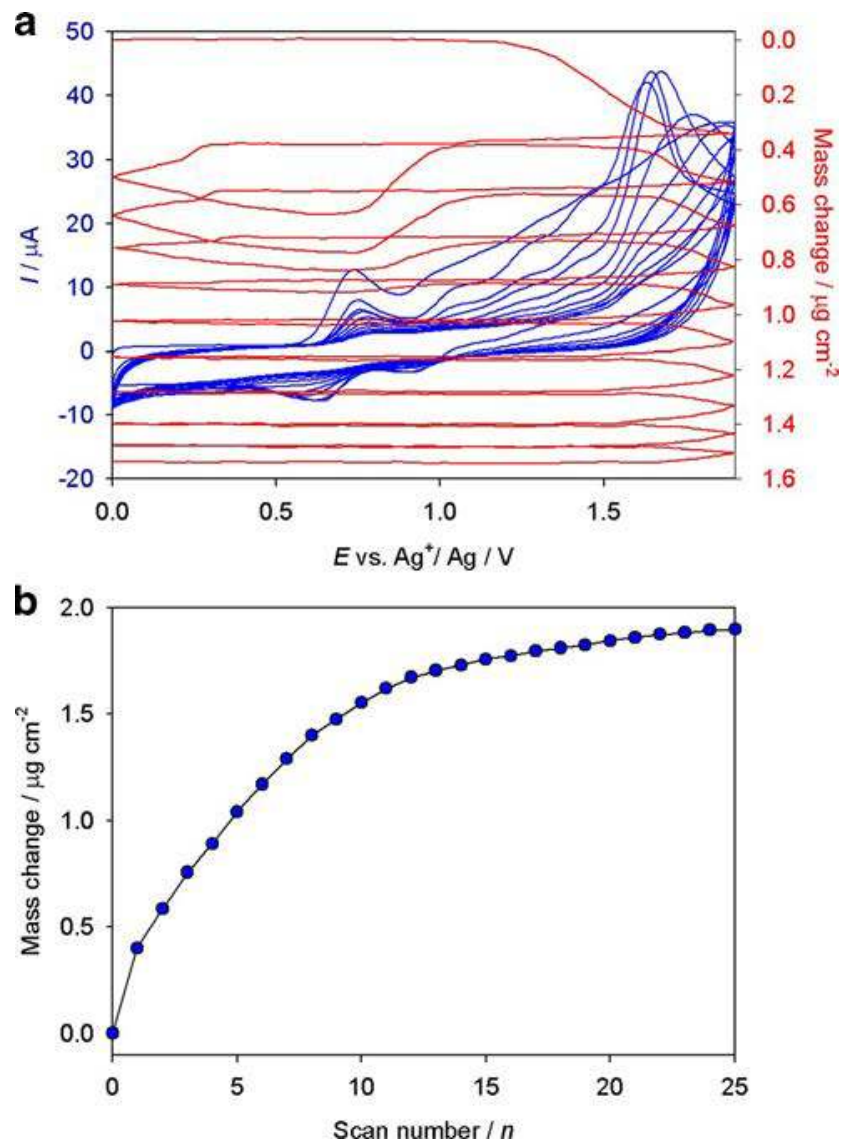

Fig. 3 a Consecutive cyclic voltammograms (first 10 scans) and electrochemical quartz crystal microbalance measurements $(\Delta m)$ for the first 10 scans during the electropolymerization of $0.25 \mathrm{mmol} \mathrm{L}^{-1} \mathrm{ZnOEP}$ with $0.25 \mathrm{mmol} \mathrm{L}^{-1} \mathrm{ib}_{\mathrm{me}} 3,3$ in $1,2-\mathrm{C}_{2} \mathrm{H}_{4} \mathrm{Cl}_{2}-\mathrm{CH}_{3} \mathrm{CN}(7 / 3)$ in the presence of $0.1 \mathrm{~mol} \mathrm{~L}^{-1} \mathrm{NBu}_{4} \mathrm{PF}_{6}$. Working electrode: ITO $(S=$ $0.2 \mathrm{~cm}^{2}$ ) deposited on a $9.08 \mathrm{MHz}$ AT-cut quartz crystal. $v=$ $100 \mathrm{mV} \mathrm{s}^{-1}$. b Mass change $(\Delta m)$ of the first 25 scans calculated from Sauerbrey's equation versus the number of scan $n$

to an increase of the large reduction peak between -0.40 and $-0.80 \mathrm{~V}$, that corresponded to the irreversible reduction of the pyridinium groups of the spacers $\left(\mathrm{Py}^{+} /\right.$ Py') and that was evidence for the formation of the film.

For poly-ZnOEP-POM-db $\mathrm{me}^{3,3}$ (Scheme 1 ), the signals between -0.50 and $-1.00 \mathrm{~V}$ observed during the first scan (Fig. 2) correspond to the reduction of the three vanadium ions in POM- $\mathrm{db}_{\mathrm{me}} 3,3$ (redox couples $\mathrm{V}^{\mathrm{V}} / \mathrm{V}^{\mathrm{IV}}$ ) which was not well defined using an ITO electrode. The redox behavior of $\mathrm{POM}-\mathrm{db}_{\mathrm{me}} 3,3$ was similar (see ESI, Fig. S3).

With iterative scans between -1.30 and $+1.90 \mathrm{~V}$, an increase of the reduction peak at $-0.91 \mathrm{~V}$ vs. SCE was observed as the copolymer was formed. This was attributed to the superimposed signals from the reduction of the forming bridging pyridiniums (Table 2) and the reduction of the vanadium atoms $\left(\mathrm{V}^{\mathrm{V}} / \mathrm{V}^{\mathrm{IV}}\right)$. 

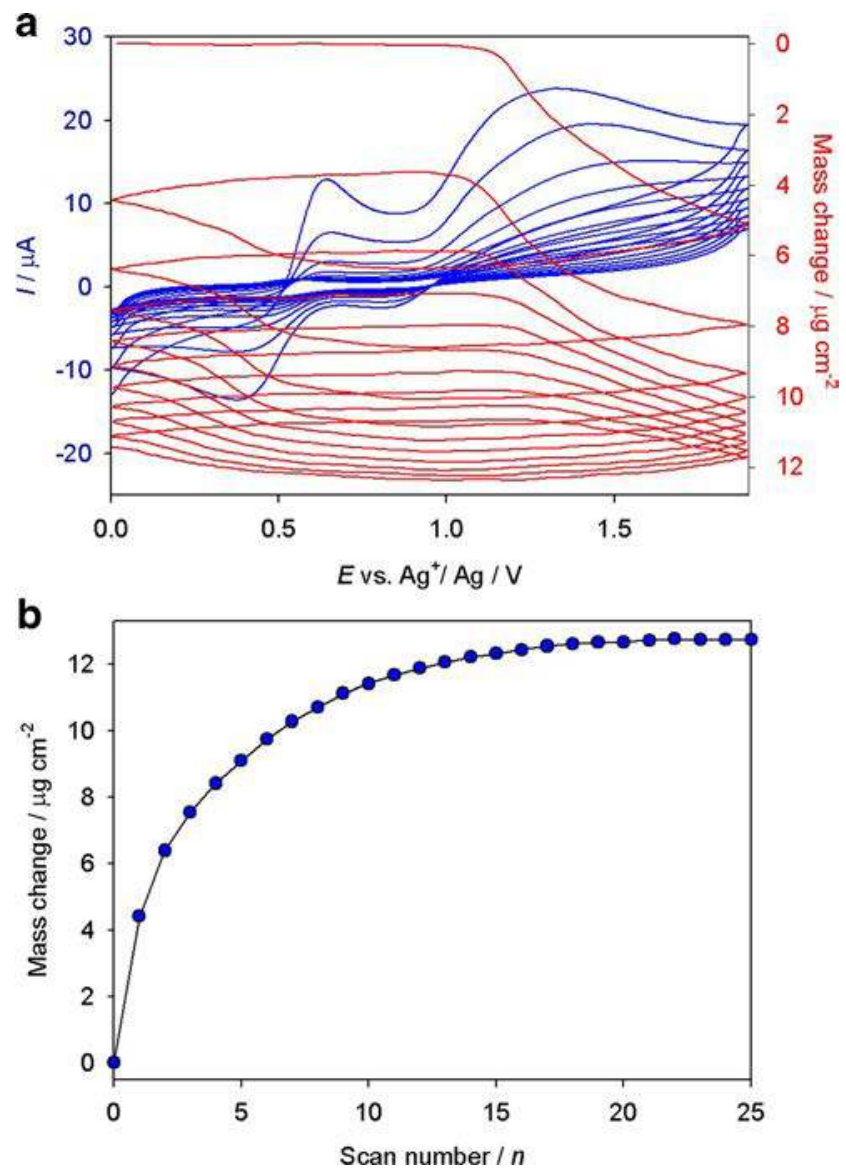

Fig. 4 a Consecutive cyclic voltammograms (first 10 scans) and electrochemical quartz crystal microbalance measurements $(\Delta m)$ for the first 10 scans during the electropolymerization of $0.25 \mathrm{mmol} \mathrm{L}^{-1} \mathrm{ZnOEP}$ with $0.25 \mathrm{mmol} \mathrm{L}-1$ POM- $\mathrm{db}_{\mathrm{me}} 3,3$ in $1,2-\mathrm{C}_{2} \mathrm{H}_{4} \mathrm{Cl}_{2}-\mathrm{CH}_{3} \mathrm{CN}(7 / 3)$ in the presence of $0.1 \mathrm{~mol} \mathrm{~L}^{-1} \mathrm{NBu}_{4} \mathrm{PF}_{6}$. Working electrode: ITO $\left(S=0.2 \mathrm{~cm}^{2}\right)$ deposited on a $9.08 \mathrm{MHz}$ AT-cut quartz crystal. $v=100 \mathrm{mV} \mathrm{s}^{-1}$. b Mass change $(\Delta m)$ of the first 25 scans calculated from Sauerbrey's equation versus the number of scan $n$.

\section{Electrochemical quartz crystal microbalance (EQCM) for the copolymer deposition}

The electrosynthesis of poly-ZnOEP-ib $\mathrm{me}^{3,3}$ and polyZnOEP-POM- $\mathrm{db}_{\mathrm{me}} 3,3$ have been monitored by EQCM. Figures 3 and 4 illustrate the simultaneously recorded mass change $(\Delta \mathrm{m})$ and cyclic voltammograms.

In the case of electropolymerisation of the ZnOEP and $\mathrm{ib}_{\mathrm{me}} 3,3$ by iterative scans between 0.00 and $+1.90 \mathrm{~V}$ (Fig. 3) and using an ITO AT-cut quartz crystal resonator, the quartz resonance frequency $(\Delta f)$ presented a decrease at each consecutive cycle, which corresponded to the increase of the copolymer mass. Using the Sauerbrey's equation [36], this change in mass was calculated and is represented in Fig. $3 \mathrm{~b}$. The smooth quartz resonance frequency decrease and thus the mass increase $(\Delta m)$ presented a continuous growth of the copolymer. Similar behavior was observed for the electropolymerization of poly-ZnOEP-POM-db me $^{3,3}$ (Fig. 4).

In the present investigation, coverage after 25 iterative scans between 0.00 and $+1.90 \mathrm{~V}$ was about 1.9 and $13.7 \mu \mathrm{g} /$ $\mathrm{cm}^{2}$ for poly-ZnOEP-ib $\mathrm{me}_{\mathrm{me}} 3,3$ and poly-ZnOEP-POM- $\mathrm{db}_{\mathrm{me}} 3$, 3 , respectively. It should be noted that the lower coverage of poly-ZnOEP-ib $\mathrm{me}_{\mathrm{me}} 3,3$ is partly explained by the molecular weight of the porphyrin used $\mathrm{ib}_{\mathrm{me}} 3,3\left(352.12 \mathrm{~g} \mathrm{~mol}^{-1}\right)$ which is much more lower than that of POM- $\mathrm{db}_{\mathrm{me}} 3,3$ (5, $586.40 \mathrm{~g} \mathrm{~mol}^{-1}$ ).

\section{Characterization by UV-visible spectroscopy of the copolymer films}

UV-visible spectra on ITO electrodes coated with the copolymers poly-ib ${ }_{m e} 3,3-Z n O E P$ and poly-POM- $\mathrm{db}_{\mathrm{me}} 3,3$-ZnOEP presented different characteristics. A typical UV-visible spectrum of poly-ib $\mathrm{m}_{\mathrm{me}} 3,3-\mathrm{ZnOEP}$ exhibited a large Soret absorption band, which was red shifted by $68 \mathrm{~nm}$ compared to the ZnOEP monomer (Table 1 and Fig. 5a). Identical spectra have previously been obtained when the macrocycle was fully substituted by pyridinium groups $[31,32]$ which strongly suggest the presence of four pyridiniums at the meso positions 5 , 10, 15, and 20 (Scheme 2).

The enlargement of the absorption bands could be explained by intra- or intermolecular excitonic interactions between the porphyrin subunits $[30,37,38]$. The red shift of the Soret and the Q bands could also been explained by the presence of the pyridinium groups in the spacer and also by the distortion of the macrocycle as already reported in the literature [31, 32].

In the case of poly-ib $\mathrm{me}_{\mathrm{me}} 3,3-\mathrm{ZnOEP}$, the very important red shift $(68 \mathrm{~nm})$ in comparison to poly-POM- $\mathrm{db}_{\mathrm{me}} 3,3-\mathrm{ZnOEP}$ could be attributable to the electron-withdrawing pyridinium groups as well as to the nonplanar saddle conformation of the porphyrin. Optical red-shifts induced by the nonplanarity of
Table 1 Spectroscopic data of $\mathrm{ZnOEP}, \mathrm{ib}_{\mathrm{me}} 3,3, \mathrm{POM}-\mathrm{db}_{\mathrm{me}} 3,3$ in $\mathrm{CH}_{3} \mathrm{CN}$, poly-ib $\mathrm{me}^{3}, 3-\mathrm{ZnOEP}$, and poly-POM-db $\mathrm{me}^{3,3-\mathrm{ZnOEP}}$ hybrid films on optical transparent ITO electrodes

\begin{tabular}{llcc}
\hline Compound & Soret band/nm & Q bands/nm & $\pi-\pi^{*}$ band $/ \mathrm{nm}$ \\
\hline $\mathrm{ZnOEP}$ & $404(414.2)$ & $533(18.7), 568(20.0)$ & \\
$\mathrm{ib}_{\mathrm{me}} 3,3$ & & & $239(27.3)$ \\
POM- $-\mathrm{db}_{\mathrm{me}} 3,3$ & & 606 & \\
poly-db $_{\mathrm{me}} 3,3-\mathrm{ZnOEP}^{\mathrm{a}}$ & 472 & 562,586 & \\
poly-POM-db & 432 & & \\
\hline
\end{tabular}

${ }^{\text {a }}$ Copolymers obtained by iterative scan between 0.00 and +1.90 V vs. SCE 

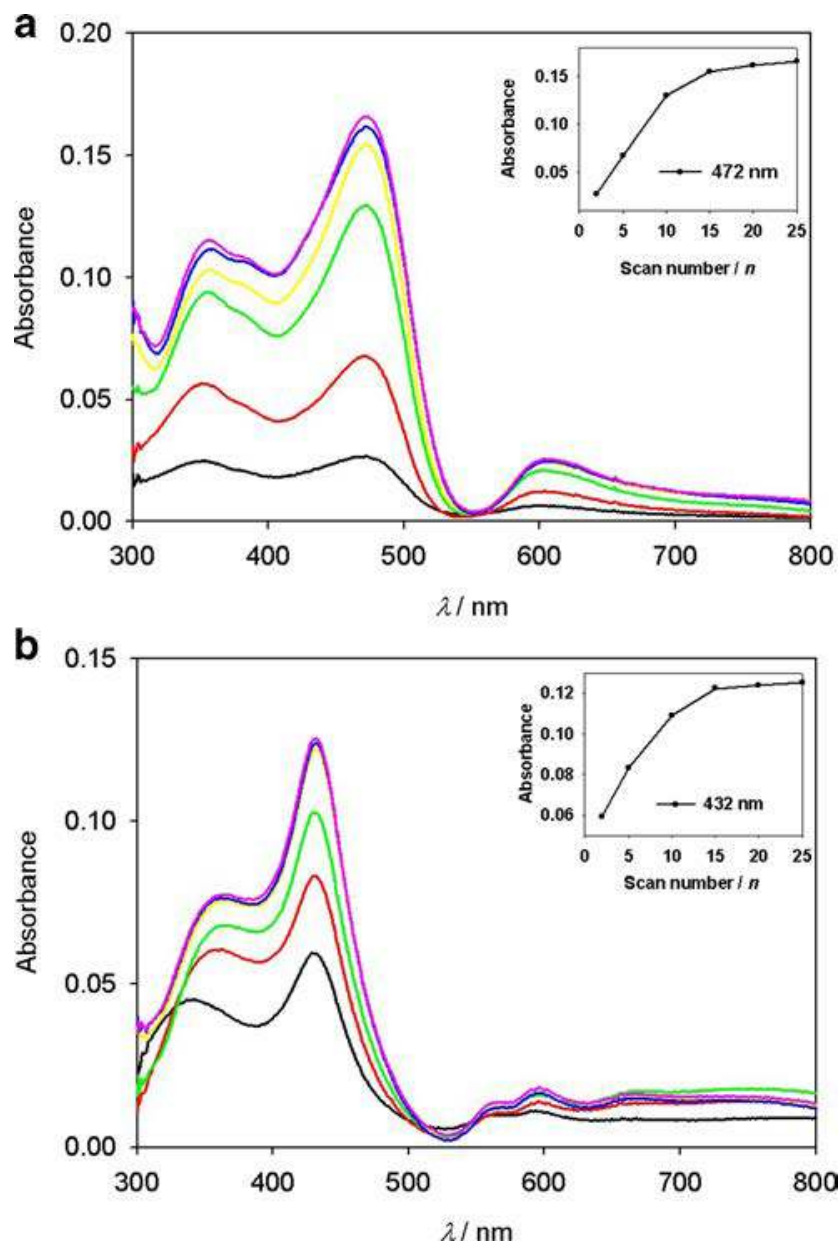

Fig. 5 UV-visible absorption spectra of a poly-ib ${ }_{\text {me }} 3,3-\mathrm{ZnOEP}$ and $\mathbf{b}$ poly-POM- $\mathrm{db}_{\mathrm{me}} 3,3-\mathrm{ZnOEP}$ onto ITO with different numbers of iterative scans between 0.00 and $+1.90 \mathrm{~V}$ vs. SCE. Only one side is covered by ITO. Inset: plots of the absorbance, measured at $\lambda=472 \mathrm{~nm}$ (a), and $\lambda=432 \mathrm{~nm}$ (b) versus the numbers of iterative scans

porphyrins are well documented $[39,40,41,42]$ and are rationalized theoretically by a larger destabilization of the highest occupied molecular orbitals (HOMOs) relative to the lowest unoccupied molecular orbitals (LUMOs) resulting in smaller HOMO to LUMO gaps [39, 40, 43, 44, 41, 42, 45, 46]. Thus, two types of connection can be proposed where the ZnOEP porphyrin are essentially fully substituted with alternating three and one linker(s) (Scheme 2, proposed structure 1), or two and two linkers (Scheme 2, proposed structure 2). Of course, various combinations and positions of the spacers are possible within the same polymer strand.

For the poly-POM- $\mathrm{db}_{\mathrm{me}} 3,3-\mathrm{ZnOEP}$, a less important red shift of $28 \mathrm{~nm}$ was detected suggesting only the bisubstitution in the meso positions 5 and 10 (cis positions) or 5 and 15 (trans positions) of the porphyrin probably due to the steric hindrance of the POM (Scheme 1).

Furthermore, for both copolymers, the absorption intensity of the chromophores increased at first progressively with each iterative scan (inset of Fig. 5a, b), and then tended to reach a plateau showing well that the thickness of the film increased with the number of iterative scans up to a given limit. Such results were already obtained in previous work [25].
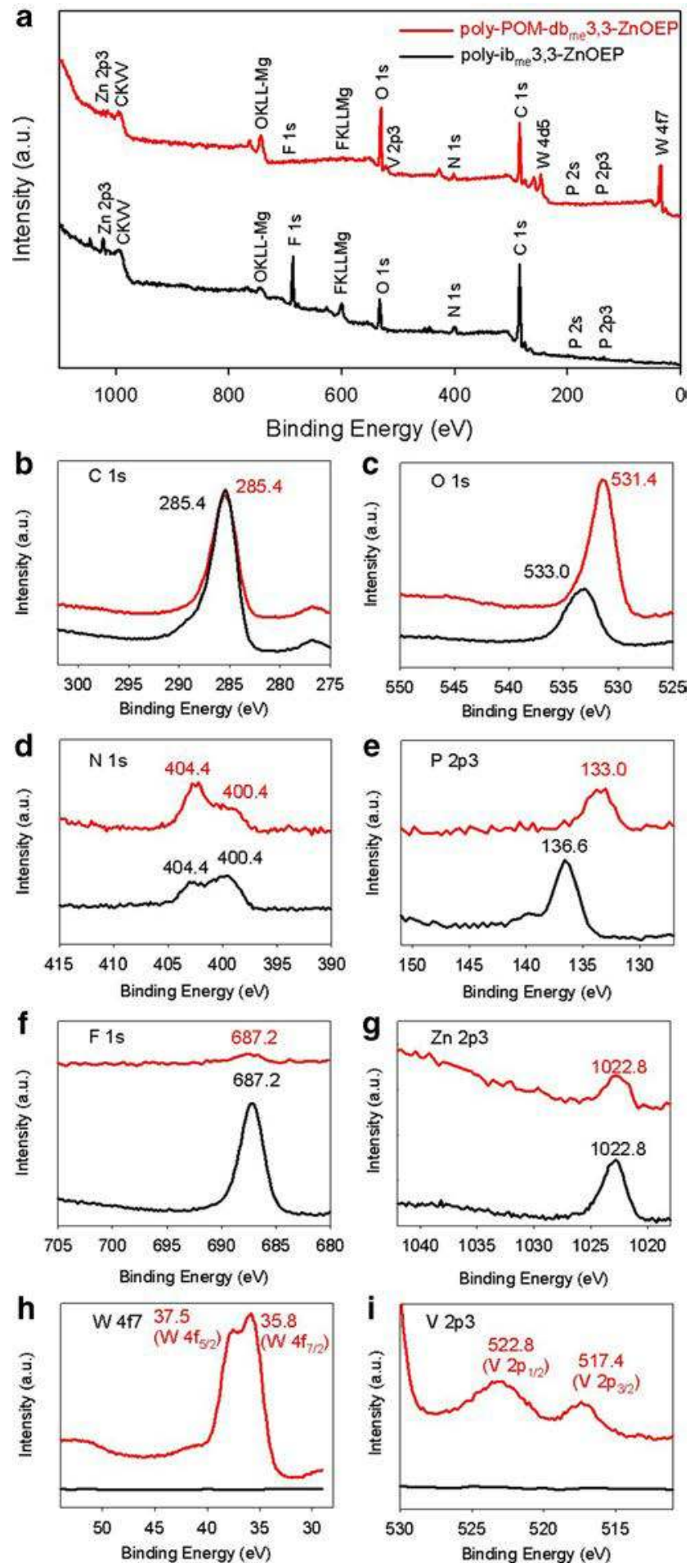

Fig. 6 XPS of poly-ib me $_{3} 3,3-Z n O E P$ (black), poly-POM- $\mathrm{db}_{\mathrm{me}} 3,3-\mathrm{ZnOEP}$ (red) films on ITO. a global XPS spectra, b C 1s, c O 1s, d N 1s, e P 2p3, f F 1 s, g Zn 2p3, h W 4f7, i V 2p3 


\section{X-ray photoelectron spectra (XPS)}

XPS was used to check the chemical composition of the films. poly-ib $\mathrm{me}_{\mathrm{me}} 3,3-\mathrm{ZnOEP}$ (Fig. 6, black curve) exhibited peaks corresponding to $\mathrm{Zn} 2 \mathrm{p} 3$ (1,022.8), O 1s (533.0), N 1s (400.4, 404.4) and $\mathrm{C} 1 \mathrm{~s}(285.4 \mathrm{eV})$ electrons, originating from the porphyrin and the dipyridyl $\mathrm{ib}_{\mathrm{me}} 3,3$ spacer, while the signals for $\mathrm{F} 1 \mathrm{~s}$ $(687.2 \mathrm{eV})$, and P 2p3 (136.6 eV) electrons came from the counterion $\mathrm{PF}_{6}{ }^{-}$that equilibrates the charges of the pyridiniums. We could notice also that for the $\mathrm{N}$ 1s electrons, two signals were detectable at 400.4 and $404.4 \mathrm{eV}$. These peaks could be assigned to the nitrogen atoms of the porphyrin (pyrrole) and of the dipyridinium spacers as well as residual tetrabutylammonium electrolyte entrapped in the film. The XPS data is compatible with the composition of the poly-ib $\mathrm{me}_{\mathrm{me}} 3,3-\mathrm{ZnOEP}$ film.

In the case of poly-POM- $\mathrm{db}_{\mathrm{me}} 3,3-\mathrm{ZnOEP}$, the peaks corresponding to $\mathrm{Zn} 2 \mathrm{p} 3, \mathrm{~N}$ 1s and $\mathrm{C} 1 \mathrm{~s}$ electrons were still detect-

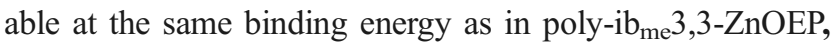
while new signals related to $\mathrm{W} 4 \mathrm{f} 7$ electrons (W $4 \mathrm{f} 7_{5 / 2}=$ $37.5 \mathrm{eV}$ and $\mathrm{W} 4 \mathrm{f}_{7 / 2}=35.8 \mathrm{eV}$ ) and $\mathrm{V} 2 \mathrm{p} 3$ electrons $\left(\mathrm{V} 2 \mathrm{p}_{1 / 2}=522.8 \mathrm{eV}\right.$ and $\left.\mathrm{V} 2 \mathrm{p}_{3 / 2}=517.4 \mathrm{eV}\right)$ appeared. These signals were coming from the vanadium, and tungsten atoms in the POM subunits. Additionally, O 1s electrons observed at $531.4 \mathrm{eV}$ corresponded only to the oxygen atoms of the POM (since the ester group of $\mathrm{ib}_{\mathrm{me}} 3,3$ was not present).

One interesting result was the quasi-disappearance of the signals at 687.2 and $136.6 \mathrm{eV}$, which came from the $\mathrm{PF}_{6}{ }^{-}$ anions. This result implies that in the copolymer poly-POM$\mathrm{db}_{\mathrm{me}} 3,3-\mathrm{ZnOEP}$ the POM subunits play the role of counterion of the pyridinium groups, which suggests that the two groups are close to each other as already evoked by the UV-vis spectrum. The signal of $\mathrm{P} 2 \mathrm{p} 3$ electrons observed at $133.0 \mathrm{eV}$ was due only to the two phosphorous atoms of POM subunits (phosphate groups).

\section{Film morphology (atomic force microscopy)}

The films were studied by scanning AFM. In a charac-

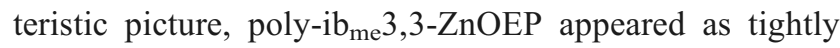
packed coils with average diameters of $60-70 \mathrm{~nm}$ and heights of 3-4 nm (Fig. 7a, b, c). The rms surface roughness of the film was $1.03-\mathrm{nm}$ for $1-\mu \mathrm{m}^{2}$ area. Poly-POM- $\mathrm{db}_{\mathrm{me}} 3,3$-ZnOEP presented comparable characteristic coils with average diameters of $70-80 \mathrm{~nm}$ and heights of 6-7 nm (Fig. 7c, d, e). Aggregation of the coils was important in the case of poly-POM- $\mathrm{db}_{\mathrm{me}} 3$, 3 -ZnOEP, which induced the increase of the rms surface roughness to $2.89 \mathrm{~nm}$.

\section{Cyclic voltammetric investigations of the two polymeric films}

The electrochemical behavior of the films has been studied by cyclic voltammetry (Table 2 and Fig. 8). In
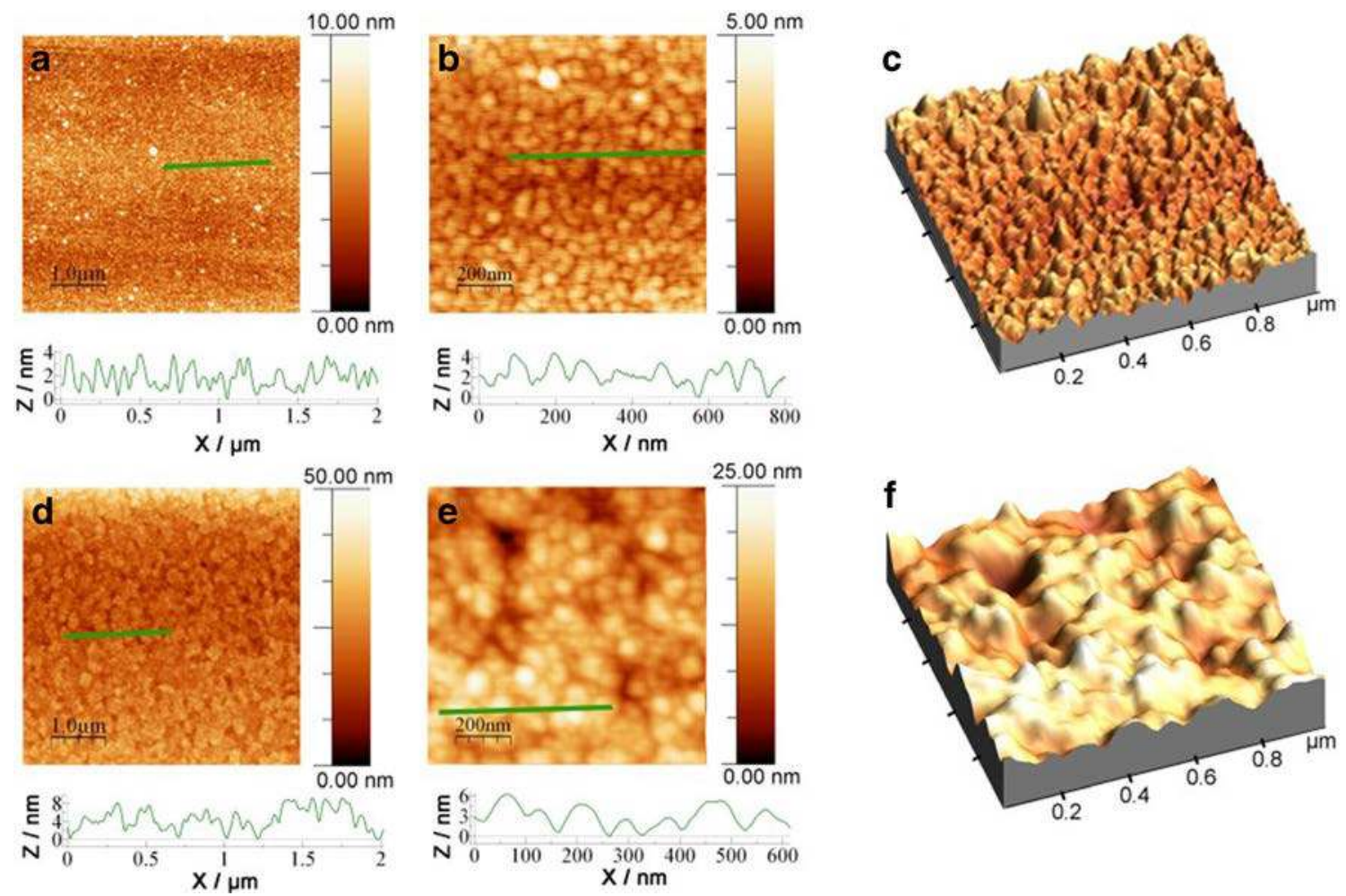

Fig. 7 Tapping mode AFM topography maps recorded for poly-ib ${ }_{m e} 3,3-Z n O E P\left(\mathbf{a}, \mathbf{b}\right.$, and $\mathbf{c}$ ), and poly-POM-db me $\left.^{3,3-Z n O E P ~(d, ~ e, ~ a n d ~} \mathbf{f}\right)$ polymer films obtained after 25 iterative scans between -1.30 and $+1.90 \mathrm{~V}$ vs. SCE 
Table 2 Electrochemical data for ZnOEP, POM-dbme3,3, polyibme3,3-ZnOEP, and poly-POMdbme3,3-ZnOEP

\begin{tabular}{|c|c|c|c|c|}
\hline & Oxidation & & Reduction & \\
\hline & $\pi$-ring & $\mathrm{V}^{\mathrm{V}} / \mathrm{V}^{\mathrm{IV}}$ & py $^{+}$spacers & $\pi$-ring \\
\hline $\mathrm{ZnOEP}^{\mathrm{a}}$ & $\begin{array}{l}+0.94,+0.68 \\
(75),(75)\end{array}$ & & & $-1.60^{\mathrm{irr}}$ \\
\hline POM-db $\mathrm{me} 3,3^{\mathrm{b}}$ & & $\begin{array}{l}-0.05,-0.45,-0.83 \\
(110),(140),(278)\end{array}$ & & \\
\hline poly-ib $\mathrm{me}^{3,3-\mathrm{ZnOEP}} \mathrm{P}^{\mathrm{c}}$ & & & $-0.40^{\mathrm{irr}},-0.51^{\mathrm{irr}},-0.67^{\mathrm{irr}},-0.78^{\mathrm{irr}}$ & $-1.60^{\mathrm{inr}}$ \\
\hline $\begin{array}{l}\text { poly-POM-db }{ }_{m e} 3,3- \\
\text { ZnOEP }^{c}\end{array}$ & & $+0.12^{\mathrm{irr}}$ & $-0.62^{\mathrm{irr}},-0.91^{\mathrm{irr}},-1.11^{\mathrm{irr}}$ & $-1.71^{\mathrm{irr}}$ \\
\hline
\end{tabular}

Potentials (in V vs. SCE) have been measured on CV curves recorded in 1,2- $\mathrm{C}_{2} \mathrm{H}_{4} \mathrm{Cl}_{2} / \mathrm{CH}_{3} \mathrm{CN}(4 / 1)$ containing $0.1 \mathrm{~mol} \mathrm{~L}^{-1} \mathrm{NBu}_{4} \mathrm{PF}_{6}$. Scan rate $=0.05 \mathrm{~V} \mathrm{~s}^{-1}$. Under bracket: $\Delta E p=\left|E p_{a}-E p_{c}\right|$

${ }^{\text {a }}$ Working electrode: Pt electrode

${ }^{\mathrm{b}}$ Working electrode: glassy carbon electrode

${ }^{c}$ Working electrode: ITO, $S=1 \mathrm{~cm}^{2}$, after 25 scans between 0.00 and $+1.90 \mathrm{~V}$ vs. SCE the case of poly-ib $\mathrm{me}_{\mathrm{e}} 3,3-\mathrm{ZnOEP}$, four reduction peaks were observed at $-0.40,-0.51,-0.67$, and $-0.78 \mathrm{~V}$, and were attributed to the successive reduction of four pyridinium spacers. Similar behavior was previously reported for ZnOEP fully substituted by four pyridiniums [32] or four bipyridinium groups [31]. These pyridinium substituents are in mutual interaction and are therefore not reduced at the same potential. Thus, electrochemistry is in agreement with UV-vis spectroscopy, and confirms the presence of four pyridinium substitutents at the meso positions of the macrocycle.

For poly-POM-db $\mathrm{me}_{\mathrm{e}} 3,3-\mathrm{ZnOEP}$ two reduction peaks appeared at +0.12 and $-0.91 \mathrm{~V}$. The former corresponds to the first reduction of one of the three vanadium atoms of the POM (couple $\mathrm{V}^{\mathrm{V} / \mathrm{IV}}$ ) while the latter corresponds to the superimposed signals from the reduction of the pyridinium spacers and the two other vanadium atoms of the polyoxovanadotungstate POM. Two smaller peaks at -0.62 and $-1.11 \mathrm{~V}$ accompany the intense peak at $-0.91 \mathrm{~V}$. Previous works concerning the pyridinium substituents of ZnOEP showed that a mutual interaction between them was observed only in the case of cis-substitutions (substitutions in 5 and 10 meso positions), leading to two successive reduction steps instead of only one. In contrast, when the two pyridinium groups are located in trans-positions ( 5 and 15 meso positions), the reductions of both pyridiniums are simultaneous [35, 47, 48]. Consequently, if the macrocycle is substituted three or four times, three or four reduction peaks of the pyridinium are observed. In the present case, our result suggest that in the copolymer poly-POM- $\mathrm{db}_{\mathrm{me}} 3,3-\mathrm{ZnOEP}$, the porphyrins were mainly bi-substituted in trans positions, and only minor cis substitution occurred.

Finally, for both films, the reductions of the porphyrin were detected at -1.38 and $-1.71 \mathrm{~V}$, respectively, at lower potential as for the spacers.
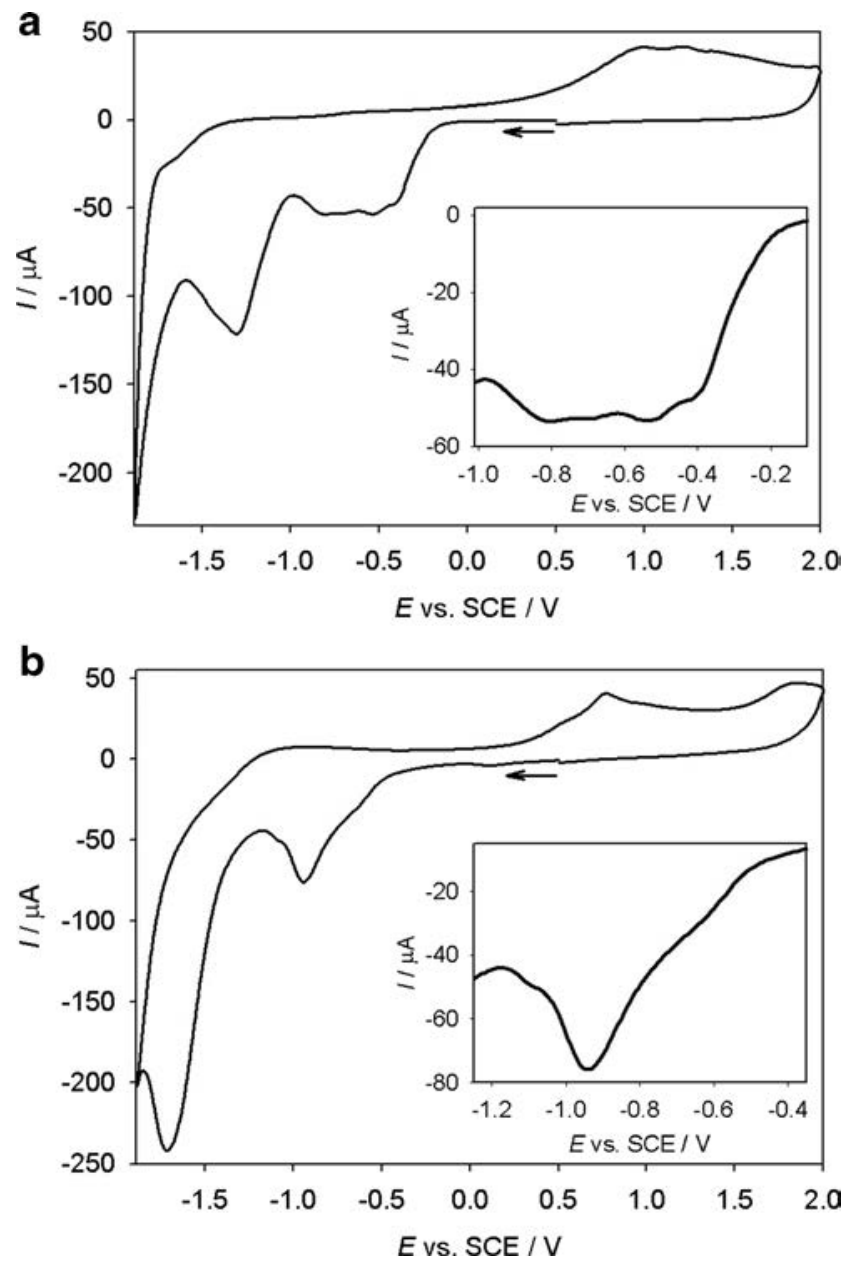

Fig. 8 Cyclic voltammograms of ITO electrodes modified with polymers obtained after 25 iterative scans from 0.00 to $+1.90 \mathrm{~V}$ vs. SCE. a poly-

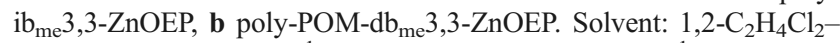
$\mathrm{CH}_{3} \mathrm{CN}(7 / 3) 0.1 \mathrm{~mol} \mathrm{~L}^{-1} \mathrm{NBu}_{4} \mathrm{PF}_{6}$, scan rate: $0.05 \mathrm{~V} \mathrm{~s}^{-1}$. Inset: zoom of the reduction peaks of the $\mathrm{V}^{\mathrm{V}}$ of the POM and of the dipyridinium spacers in the copolymers 


\section{Conclusion}

In the present paper, we report the preparation of two copolymers obtained by the anodic electro-copolymerization of Dawson-type polyoxometalate POM- $\mathrm{db}_{\mathrm{me}} 3,3$ (Py-POM-Py) or of the dipyridyl compound $i b_{m e} 3,3$, without the polyoxometalate moieties, with zinc- $\beta$-octaethylporphyrin (ZnOEP). The oxidative electropolymerization of the porphyrin in the presence of $\mathrm{POM}-\mathrm{db}_{\mathrm{me}} 3,3$ or $\mathrm{ib}_{\mathrm{me}} 3,3$ gives rise to the formation of a film on ITO electrode surfaces during repetitive potential cycling between 0.00 and $1.90 \mathrm{~V}$ vs. SCE. The oxidation of the porphyrin to give the dication is needed to start the electrodeposition and the formation of the copolymers.

The resulting films have been fully characterized by UVvisible absorption spectroscopy, X-ray photoelectron spectroscopy, atomic force microscopy, and electrochemistry. Electrochemical quartz crystal microbalance was also used to scrutinize the copolymer mass deposited.

In the case of the copolymers poly-ib $\mathrm{me}_{\mathrm{me}} 3,3$-ZnOEP, the porphyrin subunit was fully substituted at the meso positions $(5,15,20$, and 25$)$ by four pyridiniums. Indeed, the pyridiniums gave four successive reduction peaks showing that the $\mathrm{py}^{+}$were in mutual interaction. This result was in agreement also with the UV-visible spectrum which showed an important red shift $(68 \mathrm{~nm})$ attributable to the electronwithdrawing of the four pyridinium groups as well as to the nonplanar saddle conformation of the porphyrin.

In contrast, in the case of the use of the same spacer $\mathrm{ib}_{\mathrm{me}} \mathrm{e}^{3,3}$ but in the presence of the polyoxometalate (namely POM$\left.\mathrm{db}_{\mathrm{me}} 3,3\right)$, the copolymer poly-POM- $\mathrm{db}_{\mathrm{me}} 3,3-\mathrm{ZnOEP}$ obtained showed that the porphyrins appeared to be only bisubstituted. Indeed, a less important red shift $(28 \mathrm{~nm})$ was observed in agreement with the presence of the bisubstituted ZnOEP porphyrin (in two of the four meso positions). Moreover, only one bielectronic reduction for the $\mathrm{py}^{+}$groups was measured in agreement with the presence of the bisubstituted porphyrin. Two $\mathrm{py}^{+}$groups were probably in the positions 5 and 15 , positions where the pyridiniums were not in mutual interaction.

Additional optimization of this polymerization process is the next step in the development of new copolymers with designed properties. Further progress must also address the development of copolymers with dipyridyl spacers where the para positions of the pyridyl groups will be protected. In such case, reversible reduction of the pyridium groups should be obtained. Moreover, the study of the photovoltaic and/or photocatalytic performances of the copolymers described will also be carried out in the near future.

Acknowledgments We thank CNRS, the University of Strasbourg (France), Université Paris-Descartes (Paris, France), Université Pierre et Marie Curie (Paris, France), Institut de Chimie des Substances Naturelles (Gif sur Yvette, France), ECE Paris Ecole d'Ingénieurs (France), and
Fudan University (Shanghai, China) for funding of this work. We also thank the Université de Strasbourg for the projet "Idex Attractivité 2012" for supporting one part of this research, as well as the Oversea Study Program of Guangzhou Elite Project (GEP) for the Ph.D. grant to Zhaohui Huo. This work was also supported by Fund of senior visiting professor of Fudan University.

\section{References}

1. Long DL, Tsunashima R, Cronin L (2010) Angew Chem Int Ed Engl 49:1736-1758

2. Ahmed I, Farha R, Huo ZH, Allaina C, Wang XX, Xu HL, Goldmann M, Hasenknopf B, Ruhlmann L (2013) Electrochim Acta 110:726-734

3. Costa-Coquelard C, Schaming D, Lampre I, Ruhlmann L (2008) Appl Catal B Environ 84:835-842

4. Proust A, Matt B, Villanneau R, Guillemot G, Gouzerha P, Izzet G (2012) Chem Soc Rev 41:7605-76022

5. Long D-L, Burkholder E, Cronin L (2007) Chem Soc Rev 36:105121

6. Proust A, Thouvenot R, Gouzerh P (2008) Chem Commun 18371852

7. Dolbecq A, Dumas E, Mayer CR, Mialane P (2010) Chem Rev 110:6009-6048

8. Thorimbert S, Hasenknopf B, Lacôte E (2011) Isr J Chem 51:275280

9. Yokoyama A, Kojima T, Ohkubo K, Shiro M, Fukuzumi S (2011) J Phys Chem A 115:986-997

10. Allain C, Favette S, Chamoreau L, Vaissermann J, Ruhlmann L, Hasenknopf B (2008) Eur J Inorg Chem 2008:3433-3441

11. Falber A, Burton-Pye BP, Radivojevic I, Todaro L, Saleh R, Francesconi LC, Drain CM (2009) Eur J Inorg Chem 2009:2459_ 2466

12. Schaming D, Costa-Coquelard C, Lampre I, Sorgues S, Erard M, Liu X, Liu J, Sun L, Canny J, Thouvenot R, Ruhlmann L (2010) Inorg Chim Acta 363:2185-2192

13. Kang J, Xu B, Peng Z, Zhu XD, Wei YG, Powell DR (2005) Angew Chem Int Ed 44:6902-6905

14. Stark JL, Young VG, Maatta EA (1995) Angew Chem Int Ed 34: 2547-2548

15. Kang J, Nelson JA, Lu M, Xie BH, Peng ZH, Powell DR (2004) Inorg Chem 43:6408-6413

16. Odobel F, Séverac M, Pellegrin Y, Blart E, Fosse C, Cannizzo C, Mayer CR, Elliott KJ, Harriman A (2009) Chem Eur J 15:31303138

17. Matt B, Coudret C, Viala C, Jouvenot D, Loiseau F, Izzet G, Proust A (2011) Inorg Chem 50:7761-7768

18. Gao J, Liu X, Liu Y, Lingling Y, Feng YH, Chen HY, Li YX, Rakesh G, Huan CHA, Sum TC, Zhao Y, Zhang QH (2012) Dalton Trans 41:12185-12191

19. Matt B, Moussa J, Chamoreau L-M, Afonso C, Proust A, Amouri $\mathrm{H}$, Izzet G (2012) Organometallics 31:35-38

20. Elliott KJ, Harriman A, Le Pleux L, Afonso C, Proust A, Amouri H, Izzet G (2009) Phys Chem Chem Phys 11:8767-8773

21. Araghi M, Mirkhani V, Moghadam M, Tangestaninejad S, Baltorket IM (2012) Dalton Trans 41:3087-3094

22. Araghi M, Mirkhani V, Moghadam M, Tangestaninejad S, Baltorket IM (2012) Dalton Trans 41:11745-11752

23. Allain C, Schaming D, Karakostas N, Erard M, Gisselbrecht JP, Sorgues S, Lampre L, Ruhlmann L, Hasenknopf B (2013) Dalton Trans 42:2745-2754 
24. Schaming D, Allain C, Farha R, Goldmann M, Lobstein S, Giraudeau A, Hasenknopf B, Ruhlmann L (2010) Langmuir 26: 5101-5109

25. Azcarate I, Ahmed I, Farha R, Goldmann M, Wang XX, Xu HL, Hasenknopf B, Lacôte E, Ruhlmann L (2013) Dalton Trans 42: 12688-12698

26. Ruhlmann L, Schulz A, Giraudeau A, Messerschmidt C, Fuhrhop JH (1999) J Am Chem Soc 121:6664-6667

27. Ruhlmann L, Hao J, Ping Z, Giraudeau A (2008) J Electroanal Chem 621:22-30

28. Giraudeau A, Schaming D, Hao J, Farha R, Goldmann M, Ruhlmann L (2010) J Electroanal Chem 638:70-75

29. El Kahef L, Gross M, Giraudeau A (1989) J Chem Soc Chem Commun 49:1989

30. Giraudeau A, Ruhlmann L, El Kahef L, Gross M (1996) J Am Chem Soc 118:2969-2979

31. Ruhlmann L, Lobstein S, Gross M, Giraudeau A (1999) J Org Chem 64:1352-1355

32. Giraudeau A, Lobstein S, Ruhlmann L, Melamed D, Barkigia KM, Fajer J (2001) J Porphyrins Phthalocyanines 05:793-797

33. Ruhlmann L, Giraudeau A (1996) Chem Commun 2007

34. Ruhlmann L, Giraudeau A (2001) Eur J Inorg Chem 659-668

35. Schaming D, Ahmed I, Hao J, Valérie AR, Farha R, Goldmannc M, Xu HL, Giraudeaug A, Audebert P, Ruhlmann L (2011) Electrochim Acta 56:10454-10463
36. Bruckenstein S, Shay M (1985) Electrochim Acta 30:1295-1300

37. Kasha M (1959) Rev Mod Phys 31:162-169

38. Sessler JL, Johnson MR, Creager SE, Fettinger JC, Ibers JA (1990) J Am Chem Soc 112:9310-9329

39. Fajer J (2000) J Porphyrins Phthalocyanines 4:382-390

40. Shelnutt JA, Song X, Ma J-G, Jia SL, Jentzen W, Medforth CJ (1998) Chem Soc Rev 27:31-41

41. Barkigia KM, Berber MD, Fajer J, Medforth CJ, Renner MW, Smith KM (1990) J Am Chem Soc 112:8851-8857

42. Sparks LD, Medforth CJ, Park MS, Chamberlain JR, Ondrias MR, Senge MO, Smith KM, Shelnutt JA (1993) J Am Chem Soc 115: 581-592

43. Anderson ME, Barrett AGM, Hoffman BM (1999) Inorg Chem 38: 6143-6151

44. Bernard C, Gisselbrecht JP, Gross M, Vogel E, Lausmann M (1994) Inorg Chem 33:2393-2401

45. Senge MO, Renner MW, Kalisch WW, Fajer J (2000) J Chem Soc Dalton Trans 381-385

46. D'Souza F, Zandler ME, Tagliatesta P, Ou Z, Shao J, Van CE, Kadish KM (1998) Inorg Chem 37:4567-4572

47. Xia Y, Schaming D, Farha R, Goldmann M, Ruhlmann L (2012) New J Chem 36:588-596

48. Schaming D, Xia Y, Thouvenot R, Ruhlmann L (2013) Chem Eur J 19:1712-1719 